\title{
Introduction: Hal Scheffler's Extensionism in Historical Perspective and its Relevance to Current Controversies
}

\author{
Warren Shapiro and Dwight Read
}

Hal Scheffler was one of the world's great anthropologists and, without question, its foremost authority on human kinship. These considerations in themselves would be quite enough to merit a collection of essays in his memory, but his work also touches upon certain larger issues in our appreciation of the human condition, as well as current social controversies.

It was for his extensionist position on kinship terminologies-what he liked to call 'systems of kin classification'-that he was best known. In a nutshell, Scheffler would come to raise two questions: (1) What is the primary meaning — what he called the focus —of kinship terms like English 'mother', 'father', 'brother', 'sister' etc.? (2) By what procedures do people extend these meanings from their foci to others? His answers, based upon meticulous analyses of kinship terminologies in various parts of the world, were that focal membership is supplied mostly by nuclear family relationships, from which relationships it is extended to peopleeven to things - outside the nuclear family; and that these extensions are accomplished by ordered sets of rules that have considerable generality cross-culturally. 


\section{The man himself ${ }^{1}$}

Harold Walter Scheffler was born in St Louis, Missouri, United States, on 24 October 1932, to working-class parents, William C. Scheffler, an office clerk, and Dorothy C. Scheffler (née Briggs), a housewife. He registered at Southeast Missouri State College in 1952, moving to the University of Missouri the following year. Hal's quest for his first degree was interrupted by service in the United States Army (1954-55) but, after an honourable discharge, he returned to his studies, receiving a BA in anthropology and sociology in 1956 . He went on to postgraduate study at the University of Chicago, from which he received an MA in anthropology in 1957. Remaining at Chicago in pursuit of a doctorate, and with support from the Carnegie Corporation and the Fulbright Foundation, he carried out 18 months of fieldwork on the island of Choiseul in what was then the British Solomon Islands, 1960-61. This research was the basis of his $\mathrm{PhD}$ dissertation (1963), under the joint supervision of Fred Eggan and David Schneider. A revision of this work was published by the University of California Press two years later as Choiseul Island Social Structure (see below). In the interim Hal taught anthropology at the University of Connecticut and Bryn Mawr College before moving to Yale University the year he received his doctorate. He remained at Yale for four and a half decades, before retiring in 2008. Two years later he began to suffer from Parkinson's disease; he passed away from the associated dementia on 24 July 2015, survived by his wife Jan Simpson, his daughter Mary Lindholm, and a sister, Joan Wiesehan.

\section{Choiseul Island kinship}

Scheffler's first publication on kinship, based upon his doctoral dissertation, was his book-length treatment of sociality on Choiseul Island (Scheffler 1965), now part of the independent Solomon Islands. Two things deserve special emphasis in Scheffler's Choiseul analysis. First, there are rich data on distinctions made by the Choiseulese themselves. Second, Choiseulese ideas about kinship are not so different from our own.

1 We are especially indebted for this personal information from Jan Simpson, Hal's widow, her secretary Mary Smith and Ray Kelly, his Yale colleague. 
With regard to the first point, even though more distant kin are superficially classed with one's parents, siblings, children, and other close kin, these latter are said, in native parlance, to be the 'true' members of their respective kin classes (Scheffler 1965: 75, 81). The singling out of focal membership by words translatable as 'true' (or 'real') is typical of a very large number of kinship terminologies throughout the world-a point Hal Scheffler would repeatedly make in subsequent analyses (e.g. Scheffler 1972b: 354; Scheffler 1973: 766; Scheffler and Lounsbury 1971: 43) and which probably supplies the most frequently encountered evidence in the ethnographic literature for the extensionist position (Shapiro 2016, 2017). With regard to the second point, Scheffler notes an expression in the Choiseul language that he translates as 'kin', which implies that they idiomise kinship in ways that are entirely familiar to English speakers.

\section{Towards a general theory of human kinship}

A year after the publication of his Choiseul analysis, Hal Scheffler put forward nothing less than a general statement on human kinship. In this important but neglected essay Scheffler lays the groundwork for his general position on human kinship, to wit:

$[D]$ ifferent societies perceive 'the facts of procreation' differently ... but they differ within certain clear limits and have ... the same formal organization. All such theories provide for the existence of a 'genitor' and a 'genetrix' (parents), their offspring, who are related to one another (as 'siblings'), and ... for the existence of what may be called genealogical connections [among] such persons ... Kinship as a cultural phenomenon has to do first and foremost with any particular person's ... relationships with other persons as these are ... conceived to result from what his culture takes to be 'the facts of procreation.' From the point of view of any particular [person], he, his mother, and her brother do not constitute a procreatively or socially self-sufficient unit. [Instead $\mathrm{h}$ ] is father ... is as necessary to his existence as is his mother ... so ... it is the triad selfgenitor-genetrix that should be considered to be the 'atom' of kinship. For it is that unit which 'generates' the elements 'brother' and 'sister'... Clearly, then, the elementary relations of a kinship system are parent/child, husband/wife, and sibling/sibling ... These are of course the constituent relationships of the nuclear family [emphasis added] (Scheffler 1966: 83-84). 
The competing position to which Scheffler alludes is that of Claude LéviStrauss (1963: 31-54), who maintained that the irreducible elements in human kinship are those between two men, one of whom has married the other's sister, and the son of the first man. While Lévi-Strauss's schema has been challenged statistically (Ryder and Blackman 1970), Scheffler's formulation fits virtually all the data at our command.

\section{Adoption in the New Hebrides}

Scheffler's concern with kinship semantics, especially his emphasis on the distinction between focal and nonfocal members of a kin class, is developed in his article on adoption in the northern New Hebrides (Scheffler 1970b). Much earlier, based on his own fieldwork, William H.R. Rivers (1915) had argued that among some of the peoples of the New Hebrides:

the relationship of parent and child does not come into existence by the facts of procreation and parturition, but [rather] it is such acts as the payment of the midwife, the first feeding of the child, or the planting of a tree on the occasion of a birth that determine who are to be the parents of the child (Rivers 1915: 700).

Scheffler provides a counterargument based on earlier ethnographic literature on the area. He notes that in the pertinent languages one's procreative parents are distinguished from others in their kin classes by a lexical marker translatable as 'the real (or main) thing', 'very', and 'undoubted' (Scheffler 1970b: 373)—in short, they enjoy focal status in these classes. He further notes that only the 'real' parents must undergo various taboos, lest harm come to their child. 'Such beliefs and customs,' he adds, 'are virtually incomprehensible unless [the people] presume some sort of substantial and inalienable ... connection between the child and his [or her] genitor and genetrix' (ibid.: 374). Thus, by the end of 1970, Hal Scheffler had presented a general theory of human kinship and illustrated it with detailed analysis of particular ethnographic cases (see also Scheffler 1970a). 


\section{The Scheffler/Lounsbury collaboration}

The move to Yale played a vital role in the development of Scheffler's thought and hence his career. The anthropology department there had been influenced by eminent linguists such as Edward Sapir, Leonard Bloomfield and George Trager, and linguistics was widely seen to have a rigour that was lacking in much earlier ethnography circa 1950 . This move led to Hal Scheffler's collaboration with his senior colleague Floyd Lounsbury consequent upon his-Scheffler's-move to Yale in 1963. At the time Lounsbury was in the process of establishing himself as an important linguist (see especially Lounsbury 1963), and a year later he published the first two of his analyses of a system of kin classification (Lounsbury 1964a, 1964b), followed in the next year by another (Lounsbury 1965). His concern in this latter group of articles was with what he called a 'formal analysis' of the pertinent kinship terminologiesmore especially, with stipulating a focal member for each lexically labelled but unmarked kin class and then, by appealing to sets of genealogically based and ordered rules, showing that these rules could account for the allotment of kin terms to particular genealogical positions, including distant ones, as these had been recorded in, or inferred from, the pertinent ethnography. In this sense his argument was extensionist, though it was much less attuned to native distinctions than the extensionist position that Hal Scheffler was developing.

The collaboration between Scheffler and Lounsbury led to their jointly authored volume A Study in Structural Semantics: The Siriono Kinship System (1971). The Siriono are a group of nomadic hunter-gatherers in the Bolivian Amazon, known to the anthropological world primarily through a monograph by Allan Holmberg (1969). The goal of the Scheffler and Lounsbury project was to provide a formal semantic analysis of a particular kinship terminology, in the sense noted in the preceding paragraph. At the same time they were concerned with wider matters. A key point they noted is that kin terms are polysemic, that is that each term has several significata, or meanings, and these significata are semantically related. They provided the English kin term uncle as an example of such polysemy. Uncle has as one of its meanings 'my parent's brother', but it may also mean 'my aunt's husband', or even 'my grandparent's brother', that is my great-uncle. The first meaning can also be expressed, using genealogical dimensions, by the statement 'male consanguineal relative of the first ascending (i.e. the parental) generation and the first degree of collaterality', whereas 
the third definition excludes the criterion 'first ascending generation' and the second excludes the criterion 'consanguineal'. Hence the second and third meanings are, in this sense, extended versions of the meaning provided in the first definition. Nonetheless, all three meanings have to do with 'uncleness', hence the kin term uncle in English is polysemic, that is its several meanings are semantically related.

Because several critics (e.g. D’Andrade 1970; Tyler 1966; Wallace 1965) have argued that this sort of analytical procedure is more reflective of the heads of Scheffler and Lounsbury than those of 'the natives', it is well worth noting here that the latter two take considerable pains to relate their principles to Siriono understandings (Scheffler and Lounsbury 1971: 40-47). Because this concern with native conceptualisation occurs regularly in Scheffler's other writings but not in Lounsbury's, we believe its occurrence in what Hal Scheffler liked to call 'the Siriono book' reflects his influence upon his senior colleague, and probably explains why his name occurs first in their joint production.

\section{'Social paternity'}

Hal Scheffler's analysis of New Hebridean adoption was part of his project to dispel the idea that in certain communities paternity is established not by procreation but by 'social' or performative criteria, an argument put forward not only by Rivers but, as well, by more recent scholars, most notably David Schneider (1984). The most exhaustive treatment of the ubiquity of locally posited notions of biological paternity and the secondary status of 'social paternity' can be found in an encyclopedic article in which Scheffler (1973: 749-51) pointed out that the claims for an 'ignorance of physiological paternity' in the Trobriands and among Aboriginal people are without merit. Instead, the reported entry into the mother by a spiritbeing is not held to cause conception, as the 'ignorance' theory holds, but rather is posited to occur at foetal quickening: it thus appears to be a native theory of vivification of the foetus. 


\section{Baniata kin classification}

In his work subsequent to the collaboration with Lounsbury, Hal Scheffler combined his senior colleague's concern with formal analysis with his own emphasis upon explicit native theory. This can be seen in two articles he published in 1972. One of these, based upon his own fieldwork among the Baniata of the Solomon Islands (Scheffler 1972b), is, from the standpoint of anthropological debate, his most important publication. In his Introduction to this analysis he tells us that ' $[\mathrm{t}] \mathrm{he}$ principal aim of this study is to demonstrate the ethnographic [i.e. the psychological] validity, in this instance and others, of positing [rules] of [kin] terminological extension' (ibid.: 350). Scheffler further observes that kin-term product statements (see Read Chapter 2) 'may be used ... to specify extended ranges of terms. For example, the people say "the dare of my ae is my ae also," i.e. "my father's brother is my 'father' also..." (Scheffler 1972b: 350). In other words, the kin-term product of the kin term dare ('brother') and the kin term ae ('father') is the kin term ae ('father'), according to informants, and the extension of the kin term ae to the genealogical position occupied by the father's brother is through the kin-term product stipulating that 'the dare of my ae is my ae'. It should be emphasised that it is the kin-term product rule that determines the application of a kin term to a particular genealogical position beyond primary kin, not vice versa, as conventional genealogical diagrams suggest (Read 2007). Analogous considerations apply to the 'mother' and 'child' terms.

\section{Aboriginal kinship terminologies}

Scheffler's other 1972 article was an Afterword to the publication of a manuscript left by Donald Thomson, based upon that anthropologist's fieldwork on the Cape York Peninsula (Scheffler 1972a), and Scheffler's own interviews with Lauriston Sharp, who also worked on Cape York. Both of these ventures culminated in his seminal Australian Kin Classification (Scheffler 1978), one of whose chief goals was to counter 'social category' views of Aboriginal sociality. Such views had been common in Victorian theory (e.g. Fison and Howitt 1880; Lubbock 1912: 84 et seq.; Morgan 1877: 50-60), but were subsequently challenged by early twentiethcentury scholars, pointing to the apparent ubiquity of the nuclear family among Aboriginal people and the unsustainability of Victorian 
claims of communal social regimes (e.g. Lang 1905; Malinowski 1913; $\mathrm{N}$. Thomas 1906). But none of the latter had much sophistication in semantic theory. ${ }^{2}$

Australian Kin Classification, we believe, is best viewed as the culmination of the more empirically grounded studies of Aboriginal sociality that appeared in the previous decade. ${ }^{3}$ The book begins with a statement of various theories of Aboriginal kinship, including the procreatively based one sometimes espoused by A.R. Radcliffe-Brown (e.g. 1913) as well as various 'social category' perspectives. In order to lay the basis for his chief argument that Aboriginal sociality is indeed kinship based, Hal Scheffler here repeats his 1973 thesis against claims of 'ignorance of physiological paternity' among Aboriginal people. Aboriginal notions of fatherhood, he concludes, are founded upon native appreciations of the reproductive process, though augmented by a spiritual experience at foetal quickening, usually though not always undergone by the presumed genitor. ${ }^{4}$ From here he proceeds to a comprehensive and meticulous analysis of the pertinent ethnographic literature that forms the core of the book. His conclusion from all this is that:

kin-class statuses are the elementary structures of Australian [Aboriginal] social life. Originating in nuclear families and in the genealogical relations [within] them, these statuses are extended to encompass ... virtually all social relations within human communities ... Beyond this they are extended metaphorically to encompass ... social relations between human communities and the community of the Dreamtime [i.e. the mythical] beings. In this way, Australian [Aboriginal] cultures establish a moral community that embraces the cosmos ... In postulating a morally ordered universe and in attempting to comprehend it metaphorically, by analogy with the forms of their own social life, [Aboriginal] Australians demonstrate ... their intellectual kinship with the rest of [hu]man kind ... Dissent from the opinion that 'kinship' is a misnomer for ... [Aboriginal] Australian culture is likely now, no less than in the past, to encounter charges of ethnocentrism .... and of imposing alien forms on social and cultural categories that it is our first responsibility as anthropologists to comprehend ... As it happens, however, some of the concepts by which

2 For partial exceptions, see Howitt (1891) and Lang (1905: 49).

3 This is not to say that subsequent work has been without value. But none has the theoretical sweep and scholarly detail of Hal Scheffler's great work.

4 In some areas a distinction is made between the 'finder' and the genitor (Goodale 1971:137-38; Stanner 1960: 254). For a theorisation of this arrangement, including Christian baptism and other non-Aboriginal examples, see Bloch and Guggenheim (1981) and Shapiro (1988). 
[Aboriginal] Australians order their social lives - indeed ... the most fundamental concepts - are not at all alien to us or to the rest of [hu] man kind. Clothed in their own linguistic forms ... [and] elaborated upon in somewhat unusual ways, concepts of kinship are as basic as they are pervasive in [Aboriginal] Australian social life (Scheffler 1978: 530-31).

\section{Wider implications of Hal Scheffler's thought}

This last quote is key. Current kinship studies as we write are dominated by what Lounsbury (1969) called 'complete relativism', largely because of the publications and personal influence of David Schneider (e.g. 1968, 1972, 1984), who did indeed argue that kinship, at least outside the West, is a misnomer. As Scheffler lucidly points out (see below), this is disrespectful of our common humanity. In his review of Schneider's 1968 book, Scheffler (1976) was highly critical of Schneider's use of the term 'symbol', upon which Schneider's critique of kinship studies depends. Thus he-Scheffler-refers to 'Schneider's ... casual and unanalyzed use of the word [symbol] in its many ordinary, everyday senses' (ibid.: 85). More generally, Schneider's 'method' was entirely intuitive, unchecked by a concern for intellectual discipline (Fogelson 2001: 41, 53). Consider the following bit of rambling, meant to pass for 'analysis':

Sexual intercourse is love and stands as a sign of love, and love stands for sexual intercourse and is a sign of it. The two different kinds of love ... are nevertheless both symbols for unity, identity, oneness, togetherness, belonging. Love symbolizes loyalty, faith, support, help, and so forth (Schneider 1968: 52).

We alluded above to another implication of Hal Scheffler's scholarshipone which we consider most important from an intellectual standpoint. We are referring here to his emphasis upon what was once called 'the psychic unity of humankind'. Here special emphasis, we think, should be placed upon his insistence- - supported by an enormous mass of evidencethat, apparently everywhere, systems of kin classification are ordered into classes which contain focal and nonfocal members, and that the focal membership of these classes is constant, or very nearly so. More particularly, it embraces an individual's mother, father, siblings and children. These people thus everywhere constitute a conceptual unit and in most cases a residential unit as well, at least when the children are young. And in most of those few cases in which such residential unity is absent and the mother resides with her dependent children in the absence of a mate, 
sometimes augmented by one or more of her siblings, there is nonetheless not only a recognition of fatherhood but, as well, the (presumed) genitor has a special and locally recognised relationship with his children (Gough 1961: 364; Sobo 1993: 147; Stacey 2009: 247). For Scheffler, contrary to the claims of Schneider and his followers, 'the facts of procreation' viewed cross-culturally 'differ only within certain clear limits ... What all these [latter] enterprises', he observed, 'have in common is that they would deprive us of any dimensions of human, cross-cultural similarity, other than our symbol-creating capacity, by reference to which cross-cultural differences may be ordered' (Scheffler 1991: 375).

\section{Hal Scheffler and gender studies}

Hal Scheffler's work on kinship in itself is a major intellectual accomplishment—surely enough to count him among the most important anthropologists who have ever lived. But his scholarship was not confined to kinship studies. The analysis most pertinent here has to do with gender classification, which he tackled in his 1991 contribution to feminism. Several scholars (e.g. Herdt 1994; Roscoe 1994; W. Thomas 1997) have accepted at face value claims of a 'third sex' in certain nonwestern societies. But here is Scheffler's response:

Consider [the] claim that in some North American Indian societies 'gender role' rather than genital anatomy determined ... classification as a male or a female ... [This] argument is intended to liberate gender from any biological basis ... [and] to show that a system of two genders is by no means inevitable. [Such scholars] acknowledge, however, that 'gender role' is definable only as ... behavior normative for a member of one or the other genital-sex class ... and that assignment to one or the other sex class is typically at birth and not dependent on any ... behavior on the part of the person being classified. Because, logically, categories must be defined $\ldots$ by criteria independent of the normative implications of inclusion in those categories, certain forms of conduct cannot be both criteria for and normative implications of inclusion in ... the same category. It must be that [we] are dealing with situations in which some men (less often women) are permitted to act, in some degree, as though they were women (or men), and may be spoken of as though they were women (or men), or as an anomalous 'he-she' or 'she-he.' ... It is only to be expected that [one] cannot ... produce any linguistic data to demonstrate that [members of the alleged 'third sex'] are treated in any language as a genuine third gender [emphasis in original] (Scheffler 1991: 377-78). 
In short, Scheffler argues that the focal gender classes in these societies are 'male' and 'female', with the 'third gender' labels derived from these foci, just as a godfather is a specialised kind of 'father'. And the defining characteristics of these foci are genital anatomy: pertinent behaviour, Scheffler argues (e.g. 1972c: 312, 1973: 766; Scheffler and Lounsbury 1971: 39), is not logically prior but logically subsequent—just as how a father should behave is logically subsequent to those criteria that define being a father in the first place. We think it a matter of considerable intellectual importance to underscore the similarities between Scheffler's analyses of gender and his findings on kinship.

\section{Shortcoming of Scheffler's analyses}

Despite the great respect we have for Hal Scheffler's scholarship, we do not consider it beyond criticism. Recall that in his 1966 general statement on human kinship he maintained that "it is the triad self-genitor-genetrix that should be considered to be the "atom" of kinship - that is that unit which generates the elements "brother" and "sister", and that this "formal organization" is universal'. This is a prescient statement of what Dwight Read (Chapter 2; see also Read, Fischer and Lehman 2014) has called the Family Space concept. We believe this to be a necessary construct if we are to take account—as we must —of those situations in which a marriage occurs but the couple does not co-reside, those in which extramarital genitorship is recognised even in the absence of coresidence, those in which neither condition applies but the presumed genitor is nonetheless recognised, and those based upon adoption, fosterage, or the remarriage of one of the natal parents. In all of these situations genealogies may be constructed that are not-not necessarily, anyway-based upon the 'facts of procreation' that Scheffler emphasised. But although the concept was put forward while he was still active, Hal Scheffler never took note of it, nor of the pertinent ethnographic materials that made its development necessary.

\section{The essays}

Warren Shapiro's essay (Chapter 1) grounds Hal Scheffler's ideas in the classic ethnographic case of the Trobriand Islanders east of Papua New Guinea. He shows that the extensionist position is hardly new, and that 'the 
natives' themselves, quite contrary to the arguments of the performativists, really are extensionists; which is to say that, contrary to Schneider and his admirers, extensionism is not a Eurocentric imposition upon nonwestern peoples. The essay carries the implication that kin ties established through procreation are everywhere basic, as Hal Scheffler contended. By contrast, other principles upon which kinship is reckoned are everywhere logically dependent upon local procreative notions.

Dwight Read's essay (Chapter 2) considers Scheffler's extensionist argument in view of the immense ethnographic corpus on what he calls 'kin-term products'. The essay continues a project he began more than three decades ago (Read et al. 1984; see also Leaf and Read 2012; Read 2001, 2007). He demonstrates how a kinship terminology can be generated from the terms designating the relations making up a conceptual nuclear family — what he calls the Family Space (see Figure 4 in Chapter 2). The concept is rooted in mathematical theory, which will be unfamiliar to most readers, but it is empirically necessary, for reasons we have already noted. ${ }^{5}$ Using the kin-term product concept, he proceeds to work out a sort of 'grammar' for the kinship terminology. From here he shows how the genealogical employment of kin terms is derived from the 'grammar', rather than the reverse. His essay is not easy reading, so the reader should prepare, but it provides vital insights into kinship cognition. Specifically, it demonstrates how the extensionism that forms a centrepiece of Hal Scheffler's scholarship derives from the internal logic of a kinship terminology, much as we understand how the structure of English sentences derives from the (mostly unconscious) rules of English grammar.

Extensionist theory is first and foremost meant to provide richer ethnographic description. This is just what is in evidence in the essay by Andrew Strathern and Pamela Steward (Chapter 3). Their chief concern is the practical employment of kin terms among the Melpa of the Papua New Guinea Highlands. Yet at the same time they provide rich ethnographic

5 We might note here the marriage of two women among the Nuer of South Sudan (Evans-Pritchard 1951: 108-09) and elsewhere in Africa (e.g. Cadigan 1998; Krige 1974; Oboler 1980). But in all of these cases, so far as we can see, such marriages constitute only a minority of conjugal unions and in no instance is the actual genitor denied all rights with regard to the children he has sired. The commune movement in the United States in the nineteenth century and, more recently, the kibbutz movement in Israel might be thought to constitute a class of exceptions to our generalisation, but nothing is clearer in the relevant literature than the problems these arrangements have encountered in attempting to suppress the pair-bond, parents' interest in their own children, and other forms of favouritism towards close kin (e.g. Brumann 2003: 409 et seq.; Kanter 1972: 91, 158; Spiro 2004: 562). 
support for the extensionist position. Thus they report that adoptive kinship is here lexically marked relative to its procreative analogue, much like the English adoptive mother and adopted child in relation to mother and child, respectively. As we understand them, they invoke a more comprehensive notion of meaning which includes both procreative and performative significance, but at the same time they acknowledge that the latter builds upon the former. To boot, they are concerned with kinship metaphor-something with which, as we shall see, another essay deals.

In his superb summary, noted above, of what we know about human kinship, Hal Scheffler (1973: 758) stressed that kinship everywhere is reckoned through both parents-that is bilaterally. In many societies, Scheffler (ibid.: 756-65) went on to point out, this essential bilaterality is augmented by notions which are based not upon the reckoner but rather upon ancestral figures - which are, in Goodenough's terms, not 'ego-oriented' but rather 'ancestor-oriented' (Goodenough 1961). The latter are usually associated with real or posited collectivities, often involved in the control of productive property. We have known since at least 1920 that hunter-gatherers usually lack such categories (Lowie 1920: 148 et seq.). Most Amazonian societies—even the Siriono—-practise some horticulture, but Rusty Greaves and Karen Kramer (Chapter 4) worked with one group that subsists exclusively by foraging. The 'patrilocal band' model of hunter-gatherer sociality espoused by Service (1971: 46-98) does not fit here, nor are there any ancestor-oriented social categories. The sole modes of social differentiation are locality, age, sex and egooriented kinship. This last, Greaves and Kramer point out, dovetails nicely with Hal Scheffler's ideas on focality and extension.

Any general theory of human kinship must take account of attachment in early childhood (Cassidy and Shaver 2008), which is just what the essays by Fadwa El Guindi (Chapter 5) and Vicky Burbank (Chapter 6) do. Analysing her ethnographic materials on Qatari Arabs, El Guindi shows that both suckling and procreation are held to establish kinship, as does marriage. She notes a distinction between wet-nursing, which is often a paid service and which antedates Islam, and suckling. It is only the latter that has kinship connotations. Even so, kinship through suckling-usually called 'milk kinship' in the pertinent literature-is, among Qatari Arabs, locally construed to be logically derived from procreative kinship, which perforce enjoys focal status - as indeed it does, apparently, throughout the Islamic World and parts of Europe (e.g. Chapman 2012; Khatib-Chahidi 1992; Parkes 2006). Adoption, for its part, is unrecognised. 
But this is not the case amongst the Aboriginal people of Numbulwar, southeast Arnhem Land, whose sociality is the subject of Vicky Burbank's essay (Chapter 6). Here adoption is recognised as a means by which kinship is created. Now it might be thought that adoption poses problems for a theory of kinship based upon procreation, because it results in the transfer of attachment mechanisms to people other than the natal parents, or, more commonly, the sharing of these mechanisms with those parents (Silk 1987). Warren Shapiro, however, has shown that adoption seems usually not to affect this theory, that is that natal parents retain focal status in the local 'parent' categories (Shapiro 2016). Burbank presents a partly contrary case. At Numbulwar both adoptive and procreative kin are said to be 'close family' in the local creole, but the latter are said to be 'closer' than the former. This suggests a 'layered' focality, something which Hal Scheffler noted in his Choiseul analysis (Scheffler 1965: 74) and which Shapiro found in his research among the Aboriginal people of northeast Arnhem Land (Shapiro 1981: 38-40). Moreover, the 'close' status of adoptive kin at Numbulwar suggests a rapprochement between extensionists and performativists.

Just as Hal Scheffler's ideas have relevance for more searching ethnographic analyses, so they shed light on historical process. Thus Pat McConvell (Chapter 7) considers the extensive research done by Scheffler on Aboriginal kinship terminologies as a basis for enquiry into historical change in these terminologies, as well as for the reconstruction of their ancient predecessors. He shows that these reconstructions fit well with extensionist theory, particularly in the ways in which this theory illuminates their semantic properties. But, like Strathern and Stewart, he thinks that extensionism needs to be augmented by a consideration of the pragmatic usage of kin terms. McConvell further points out that not all semantic change in the pertinent terminologies fits what might be predicted from Scheffler's seminal analysis of such systems (Scheffler 1978): some, for example, disrespect gender and generational classes.

So, however valuable they are, we ought not to regard Hal Scheffler's ideas as Received Truth. In fact, Warren Shapiro, in his role as editor, made a point of inviting scholars with a track record of contesting Scheffler's thought to participate in this Festschrift. Thus Scheffler was critical of the idea that an 'alliance' relationship is foundational to human kinship (e.g. Scheffler 1970b, 1973: 780-86, 1977). It needs to be added here that, after his initial formulation of what would come to be called 'alliance theory', noted above, Lévi-Strauss (1949) would develop his scheme into 
one emphasising societies with paternally (or, less often, maternally) based groups that regularly intermarry, as opposed to those in which such groups exist but prefer to scatter their marriages among a large number of equivalent groups, and those that have no such groups. In the former class of societies, he maintained, kinship terms are not polysemic: rather, each has a single meaning, and this meaning refers primarily to intergroup relations and only incidentally to close kin. This might be considered a variety of the 'social categories' position. Bob Parkin (Chapter 8), the only 'alliance theorist' who has taken serious account of the extensionist position, is here concerned with the disappearance of regular intermarriage between groups. He points out that this disappearance stems from nonmarital factors which prevent group interaction. Otherwise he maintains the 'alliance theory' position on kin terms. His essay, however, does not counter Hal Scheffler's viewpoint that kin terms in societies with intermarrying groups are like kin terms everywhere else: their foci are close procreative kin, from which they are extended to others, including those related by marriage.

The 'performativist' view of kinship is taken up in Linda K. Watts's essay (Chapter 9). Previously, Watts had authored two exceptional analyses of the kinship terminology of the Zuni of New Mexico (Watts 1997, 2000) in which she seriously engaged the extensionist position. For her, the expression 'kinship terminology' is a misnomer: she prefers 'relational terminology', because, she has argued, the foci of the terms in question are provided by people with whom one is especially close emotionally, who may or may not be close procreative kin. The argument is pursued further in this volume. Her essay is without question the most passionate and erudite defence to date of the performativist position. As such, it invites a rethinking of the extensionist theory, though not, we think, an abandonment of it.

Watts also stresses the necessity for richer linguistic analysis in kinship studies, which we fully endorse. She draws attention to the fact that such an analysis of a 'relational terminology' would be more encompassing than one concerned solely with terms of reference, which have received by far the most attention in kinship studies: here her position is similar to those taken in several of the other essays in this volume, particularly those of Strathern and Stewart, Burbank, and McConvell. Watts's advocacy would, she notes, lead to a fuller appreciation of the range of relations an individual has with others. Thus the native terms that anthropologists 
translate as 'mother' and 'father' do indeed, we think, have primary reference to procreation, but this does not preclude extensive connotative meaning.

This links up with Bojka Milicic's essay (Chapter 10). But while Watts's chapter is concerned with synchronic ethnographic studies, Milicic pursues the role of metaphor in human thought more generally, including its possible origin as one of the ways by which kinship is conceptualised. Kinship and metaphor, she points out, are both fundamentally relational: kinship involves the relation of individuals to one another, metaphor the relation of one semantic domain to another through analogy, as when her Croatian informants liken their kinship networks to winding clusters of plants. Milicic suggests that, in the course of human evolution, thinking about kinship is what led to metaphorical thought. Her essay thus deals with an area noted but insufficiently explored by Hal Scheffler, but, like his concern with focality in nonmetaphorical kinship, she roots it in our species' heritage.

Doug Jones's essay (Chapter 11), like McConvell's, is concerned with historical change in kinship terminologies, but, like Milicic's, it focuses upon more general properties of human thought. More specifically, his focus is on how these properties impose internal constraints on change in systems of kin classification. Such systems, he suggests, display a degree of cross-cultural regularity suggestive of a common structural foundation, and this foundation transcends variation in local theories of procreation. The suggestion, then, is that Hal Scheffler's ideas, relying as they do on such theories, need to be supplemented. In the same vein, Jones expands the extensionist argument by calling attention to certain constraints on kin-term usage not considered by Scheffler.

An even more unabashedly innatist position is taken in the essay by Michelle Escasa-Dorne and Bill Jankowiak (Chapter 12), whose argument dovetails nicely with Hal Scheffler's interest in gender. Just as Scheffler's analysis provides no support for modish claims about gender classification, so the findings of Escasa-Dorne and Jankowiak square not at all with current arguments concerning gender equality in sexual behaviour. More specifically, these two scholars studied partner-preferences as indicated on Internet dating sites; since one can be largely anonymous on such sites, it might be expected that women would be more inclined to shake off what could be called 'conservative' social views, and more inclined consequently to approximate men in this area. But, it turns out, this is anything but 
the case: even on the Internet men evidence significantly more interest in casual sex with multiple partners than women do, whereas when it comes to committed relationships the reverse is true. We should perhaps emphasise here, especially given the political climate in academia these days, that the tendencies discovered by Escasa-Dorne and Jankowiak are just that-tendencies. Their research found that some men prefer committed relationships, some women casual sex with multiple partners. Biology is not destiny: it is likelihood. All of the chapters in this Festschrift, in fact, should be read with this in mind.

\section{Conclusion}

Even an Introduction should have one. We believe we now have a general theory of human kinship that is consistent with all the data at our command: kinship is primarily about locally posited procreative ties, thence extended to other social relationships, as well as to construed relationships with the phenomena of nature and of people's imagination. Moreover, the relation of all this to the nuclear family, though not absolute, is strongly tendential. These are truly monumental conclusions, and we have Hal Scheffler most of all to thank for them. We hope that the essays that follow are worthy of this remarkable scholar.

\section{Acknowledgements}

We are grateful to Tom Parides for reading earlier versions of this Introduction. It remains, nonetheless, our own responsibility.

\section{References}

Basso, Keith H. and Henry A. Selby (eds). 1976. Meaning in Anthropology. Albuquerque: University of New Mexico Press.

Bloch, Maurice and Stephen Guggenheim. 1981. 'Compadrazgo, baptism and the symbolism of a second birth'. Man (n.s.) 16(3): 376-86. doi.org/10.2307/2801290 
Brumann, Christoph. 2003. "'All the flesh kindred that ever I see": A reconsideration of family and kinship in utopian communes'. Comparative Studies in Society and History 45(2): 395-421. doi.org/ $10.1017 /$ S0010417503000197

Cadigan, R. Jean. 1998. 'Woman-to-woman marriage: Practices and benefits in Sub-Saharan Africa'. Journal of Comparative Family Studies 29(1): 89-98.

Carroll, Vern (ed.). 1970. Adoption in Eastern Oceania. Association for Social Anthropologists in Oceania Monograph 1. Honolulu: University of Hawaii Press.

Cassidy, Jude and Phillip R. Shaver (eds). 2008. Handbook of Attachment: Theory, Research, and Clinical Applications. 2nd edition. New York: The Guilford Press.

Chapman, Cynthia R. 2012. "'Oh that you were like a brother to me, one who had nursed at my mother's breasts": Breast-milk as a kinshipforging substance'. Journal of Hebrew Scriptures 12: 1-41. doi.org/ 10.5508/jhs.2012.v12.a7

D'Andrade, Roy G. 1970. 'Structure and syntax in the semantic analysis of kinship terminologies'. In Cognition: A Multiple View, edited by Paul L. Garvin, 87-114. New York: Spartan Books.

di Leonardo, Micaela (ed.). 1991. Gender at the Crossroads of Knowledge: Feminist Anthropology in the Postmodern Era. Berkeley, CA: University of California Press.

Evans-Pritchard, E.E. 1951. Kinship and Marriage among the Nuer. Oxford: Clarendon Press.

Feinberg, Richard and Martin Ottenheimer (eds). 2001. The Cultural Analysis of Kinship: The Legacy of David M. Schneider. Urbana, IL: University of Illinois Press.

Fison, Lorimer and A.W. Howitt. 1880. Kamilaroi and Kurnai. Melbourne: G. Robertson.

Fogelson, Raymond D. 2001. 'Schneider confronts componential analysis.' In The Cultural Analysis of Kinship: The Legacy of David M. Schneider, edited by Richard Feinberg and Martin Ottenheimer, 33-45. Urbana, IL: University of Illinois Press. 
Garvin, Paul L. (ed.). 1970. Cognition: A Multiple View. New York: Spartan Books.

Goodale, Jane C. 1971. Tiwi Wives: A Study of the Women of Melville Island, North Australia. American Ethnological Society Monograph 51. Seattle: University of Washington Press.

Goodenough, Ward H. 1961. 'Comments on cultural evolution'. Daedalus 90: 521-28.

Gough, E. Kathleen. 1961. 'Nayar: Central Kerala'. In Matrilineal Kinship, edited by David M. Schneider and Kathleen E. Gough, 298-384. Berkeley, CA: University of California Press.

Hammel, Eugene A. (ed.). 1965. Formal Semantic Analysis. American Anthropologist Special Publications. Menasga, WI: American Anthropological Association.

Herdt, Gilbert. 1994. 'Preface'. In Third Sex, Third Gender: Beyond Sexual Dimorphism in Culture and History, edited by Gilbert Herdt, 11-20. New York: Zone Books.

Herdt, Gilbert (ed.). 1994. Third Sex, Third Gender: Beyond Sexual Dimorphism in Culture and History. New York: Zone Books.

Holmberg, Allan R. 1969. Nomads of the Long Bow: The Siriono of Eastern Bolivia. Garden City, NY: Natural History Press.

Honigmann, John J. (ed.). 1973. Handbook of Social and Cultural Anthropology. Chicago: Rand McNally.

Hook, Sidney (ed.). 1969. Language and Philosophy. New York: New York University Press.

Howitt, A.W. 1891. 'The Dieri and other kindred tribes of central Australia'. Journal of the Royal Anthropological Institute of Great Britain and Ireland 20: 30-104. doi.org/10.2307/2842347

Jacobs, Sue-Ellen, Wesley Thomas and Sabine Lang (eds). 1997. Two-spirit People: Native American Gender Identity, Sexuality, and Spirituality. Urbana, IL: University of Illinois Press. 
Kanter, Rosabeth M. 1972. Commitment and Community: Communes and Utopias in Sociological Perspective. Cambridge: Harvard University Press.

Khatib-Chahidi, Jane. 1992. 'Milk kinship in Shi' ite Islamic Iran'. In The Anthropology of Breast-Feeding: Natural Law or Social Construct, edited by Vanessa Maher, 109-32. Oxford: Berg.

Krige, Eileen J. 1974. 'Woman-marriage, with special reference to the Louedu. Its significance for the definition of marriage'. Africa: Journal of the International African Institute 44(1):11-37. doi.org/ $10.2307 / 1158564$

Lang, Andrew. 1905. The Secret of the Totem. New York: Longmans, Green \& Co.

Leaf, Murray J. and Dwight Read. 2012. The Conceptual Foundation of Human Society and Thought: Anthropology on a New Plane. Lanham, MD: Lexington Books.

Lévi-Strauss, Claude. 1949. Les structures élémentaires de la parenté. Paris: Presses Universitaires Françaises; rev. and trans. James Harle Bell and John Richard von Sturmer, ed. Rodney Needham as The Elementary Structures of Kinship. Boston: Beacon Press, 1969 (page citations are to the translated edition).

—. 1963. Structural Anthropology. New York: Basic Books.

Lounsbury, Floyd G. 1963. 'Linguistics and psychology'. In Psychology: A Study of a Science, edited by Sigmund Koch, 552-82. New York: McGraw-Hill. doi.org/10.1037/10590-010

— 1964a. 'A formal account of the Crow- and Omaha-type kinship terminologies'. In Explorations in Cultural Anthropology: Essays in Honor of George Peter Murdock, edited by Ward H. Goodenough, 351-93. New York: McGraw-Hill.

- 1964b. 'The structural analysis of kinship semantics'. In Proceedings of the Ninth International Congress of Linguistics, edited by H.G. Lunt, 1073-93. The Hague: Mouton. 
. 1965. 'Another view of the Trobriand kinship categories'. In Formal Semantic Analysis, edited by Eugene A. Hammel. Special issue of American Anthropologist (n.s.) 67(5) Part 2: 142-85. doi.org/10.1525/ aa.1965.67.5.02a00770

- _. 1969. 'Language and culture'. In Language and Philosophy: A Symposium, edited by Sidney Hook, 3-29. New York: New York University Press.

Lowie, Robert H. 1920. Primitive Society. New York: Boni and Liveright.

Lubbock, John. 1912. The Origin of Civilisation and the Primitive Condition of Man: Mental and Social Condition of Savages. London: Longmans, Green and Co.

Lunt, H.G. (ed.). 1964. Proceedings of the Ninth International Congress of Linguistics. The Hague: Mouton.

Maher, Vanessa (ed.). 1992. The Anthropology of Breast-Feeding: Natural Law or Social Construct. Oxford: Berg.

Malinowski, Bronisław. 1913. The Family among the Australian Aborigines: A Sociological Study. London: University of London Press.

Morgan, Lewis H. 1877. Ancient Society; or Researches in the Lines of Human Progress from Savagery, through Barbarism to Civilization. New York: Henry Holt.

Oboler, Regine S. 1980. 'Is the female husband a man? Woman/woman marriage among the Nandi of Kenya'. Ethnology 19(1): 69-88. doi.org/10.2307/3773320

Parkes, Peter. 2006. 'Celtic fosterage: Adoptive kinship and clientage in northwest Europe'. Comparative Studies in Society and History 48(2): 359-95. doi.org/10.1017/S0010417506000144

Radcliffe-Brown, A.R. (Alfred Reginald). 1913. 'Three tribes of Western Australia'. Journal of the Royal Anthropological Institute 43: 143-94. doi.org/10.2307/2843166

Read, Dwight W. 2001. 'What is kinship?' In The Cultural Analysis of Kinship: The Legacy of David M. Schneider, edited by Richard Feinberg and Martin Ottenheimer, 78-117. Urbana, IL: University of Illinois Press. 
—. 2007. 'Kinship theory: A paradigm shift'. Ethnology 46(4): 329-64.

Read, Dwight, John Atkins, Ira R. Buchler ... William D. Wilder. 1984. 'An algebraic account of the American kinship terminology'. Current Anthropology 25(4): 417-40. doi.org/10.1086/203160

Read, Dwight, Michael D. Fischer, Kris Lehman (Chit Hlaing). 2014. 'The cultural grounding of kinship: A paradigm shift'. L'Homme 210(2): 63-89. doi.org/10.4000/lhomme. 23550

Reining, Priscilla (ed.). 1972. Kinship Studies in the Morgan Centennial Year. Washington: The Anthropological Society of Washington.

Rivers, William H.R. 1915. 'Kin, kinship'. In Encyclopedia of Religion and Ethics, vol. 7, 700-07.

Roscoe, Will. 1994. 'How to become a berdache: Toward a unified analysis of gender diversity'. In Third Sex, Third Gender: Beyond Sexual Dimorphism in Culture and History, edited by Gilbert Herdt, 32-72. New York: Zone Books.

Ryder, James W. and Margaret B. Blackman. 1970. 'The avunculate: A cross-cultural critique of Claude Lévi-Strauss'. Cross-Cultural Research 5(2): 97-115. doi.org/10.1177/106939717000500202

Scheffler, Harold W. 1965. Choiseul Island Social Structure. Berkeley: University of California Press.

- 1966. 'Structuralism in anthropology'. Yale French Studies 36-37: 66-88. doi.org/10.2307/2930400

- 1970a. 'Kinship and adoption in the northern New Hebrides'. In Adoption in Eastern Oceania, edited by Vern Carroll, 369-89. Association for Social Anthropologists in Oceania Monograph 1. Honolulu: University of Hawaii Press.

— 1970b. 'The Elementary Structures of Kinship, by Claude LéviStrauss: A review article'. American Anthropologist 72: 251-68. doi.org/10.1525/aa.1970.72.2.02a00020

- 1972a. 'Afterword'. In Kinship and Behaviour in North Queensland: A Preliminary Account of Kinship and Social Organisation on Cape York Peninsula, by Donald Thomson, 37-52. Australian Aboriginal Studies No. 51. Canberra: Australian Institute of Aboriginal Studies. 
—_. 1972b. 'Baniata kin classification: The case for extensions'. Southwestern Journal of Anthropology 28(4): 350-81. doi.org/10.1086/ soutjanth.28.4.3629317

_- 1972c. 'Kinship semantics'. Annual Review of Anthropology 1: 309-28. doi.org/10.1146/annurev.an.01.100172.001521

—_. 1973. 'Kinship, descent, and alliance'. In Handbook of Social and Cultural Anthropology, edited by John J. Honigmann, 747-93. Chicago: Rand McNally.

_- 1976. "The "meaning" of kinship in American culture: another view'. In Meaning in Anthropology, edited by Keith H. Basso and Henry A. Selby, 57-91. Albuquerque: University of New Mexico Press.

—_. 1977. 'Review: Kinship and alliance in South India and Australia'. American Anthropologist 79(4): 869-82. doi.org/10.1525/ aa.1977.79.4.02a00060

1978. Australian Kin Classification. Cambridge Studies in Social Anthropology No. 23. Cambridge: Cambridge University Press. doi.org/10.1017/CBO9780511557590

- 1991 . 'Sexism and naturalism in the study of kinship'. In Gender at the Crossroads of Knowledge: Feminist Anthropology in the Postmodern Era, edited by Micaela di Leonardo, 361-82. Berkeley, CA: University of California Press.

Scheffler, Harold W. and Floyd G. Lounsbury. 1971. A Study in Structural Semantics: The Siriono Kinship System. Englewood Cliffs, NJ: Prentice Hall.

Schneider, David M. 1968. American Kinship: A Cultural Account. Englewood Cliffs, NJ: Prentice Hall.

__ 1972. 'What is kinship all about?' In Kinship Studies in the Morgan Centennial Year, edited by Priscilla Reining, 32-63. Washington: Anthropological Society of Washington.

- - 1984. A Critique of the Study of Kinship. Ann Arbor, MI: The University of Michigan Press. doi.org/10.3998/mpub.7203

Schneider, David M. and Kathleen Gough (eds). 1961. Matrilineal Kinship. Berkeley, CA: University of California Press. 
Service, Elman R. 1971. Primitive Social Organization: An Evolutionary Perspective. New York: Random House.

Shapiro, Warren. 1981. Miwuyt Marriage: The Cultural Anthropology of Affinity in Northeast Arnhem Land. Philadelphia: Institute for the Study of Human Issues.

- 1988. 'Ritual kinship, ritual incorporation, and the denial of death'. Man (n.s.) 23(2): 275-97. doi.org/10.2307/2802806

— 2016. 'Why Schneiderian kinship studies have it all wrong: With special reference to adoptive kinship'. Structure and Dynamics 9(2): 218-39. Online: escholarship.org/uc/item/1vp7c25g (accessed 31 May 2017).

- 2017. 'Toward a post-Schneiderian perspective on kinship'. Journal of Anthropological Research 73(2): 238-61. doi.org/10.1086/692004

Silk, Joan B. 1987. 'Adoption and fosterage in human societies: Adaptations or enigmas?' Cultural Anthropology 2(1): 39-49. doi.org/ $10.1525 /$ can.1987.2.1.02a00050

Sobo, Elisa J. 1993. One Blood: The Jamaican Body. Albany: State University of New York Press.

Spiro, Melford E. 2004. 'Utopia and its discontents: The kibbutz and its historical vicissitudes'. American Anthropologist 106(3): 556-68. doi.org/10.1525/aa.2004.106.3.556

Stacey, Judith. 2009. 'Unhitching the horse from the carriage: Love and marriage among the Mosuo'. Utah Law Review 11: 287-321.

Stanner, William E.H. 1960. 'On Aboriginal religion. II: Sacramentalism, rite and myth'. Oceania 30(4): 245-78. doi.org/10.1002/j.18344461.1960.tb00226.x

Thomas, Northcote W. 1906. Kinship Organisations and Group Marriage in Australia. Cambridge: Cambridge University Press.

Thomas, Wesley. 1997. 'Navajo cultural constructions of gender and sexuality'. In Two-spirit People: Native American Gender Identity, Sexuality, and Spirituality, edited by Sue-Ellen Jacobs, Wesley Thomas and Sabine Lang, 156-73. Urbana, IL: University of Illinois Press. 
Tyler, Stephen A. 1966. 'Whose kinship reckoning? Comments on Buchler'. American Anthropologist 68(2): 513-16. doi.org/10.1525/ aa.1966.68.2.02a00240

Wallace, Anthony F.C. 1965. 'The problem of the psychological validity of componential analysis'. In Formal Semantic Analysis, edited by Eugene A. Hammel, 229-48. American Anthropologist Special Publication. Menasha, WI: American Anthropological Association.

Watts, Linda K. 1997. 'Zuni family ties and household group values: a revisionist cultural model of Zuni social organization'. Journal of Anthropological Research 53(1): 17-29.

- 2000. The Social Semiotics of Relational Terminology at Zuni Pueblo. Lewiston, NY: Edward Mellen Press. 
This text is taken from Focality and Extension in Kinship: Essays in Memory of Harold W. Scheffler, edited by Warren Shapiro, published 2018 by ANU Press, The Australian National University, Canberra, Australia.

doi.org/10.22459/FEK.04.2018.00 